\title{
Peer-Based Social Media Features in Behavior Change Interventions: Systematic Review
}

Sheik Mohammad Roushdat Ally Elaheebocus ${ }^{1,2}$, MSc; Mark Weal $^{1}, \mathrm{PhD}$; Leanne Morrison ${ }^{3}, \mathrm{PhD}$; Lucy Yardley ${ }^{3}$, $\mathrm{PhD}$

\footnotetext{
${ }^{1}$ School of Electronics and Computer Science, University of Southampton, Southampton, United Kingdom

${ }^{2}$ Department of Digital Technologies, Faculty of Information, Communication and Digital Technologies, University of Mauritius, Reduit, Mauritius

${ }^{3}$ Academic Unit of Psychology, Faculty of Social, Human, and Mathematical Sciences, University of Southampton, Southampton, United Kingdom
}

\section{Corresponding Author:}

Sheik Mohammad Roushdat Ally Elaheebocus, MSc

Department of Digital Technologies

Faculty of Information, Communication and Digital Technologies

University of Mauritius

Rm 3.10 Phase II, FoA

Reduit,

Mauritius

Phone: 23058040525

Email: r.elaheebocus@uom.ac.mu

\begin{abstract}
Background: Incorporating social media features into digital behavior change interventions (DBCIs) has the potential to contribute positively to their success. However, the lack of clear design principles to describe and guide the use of these features in behavioral interventions limits cross-study comparisons of their uses and effects.

Objective: The aim of this study was to provide a systematic review of DBCIs targeting modifiable behavioral risk factors that have included social media features as part of their intervention infrastructure. A taxonomy of social media features is presented to inform the development, description, and evaluation of behavioral interventions.

Methods: Search terms were used in 8 databases to identify DBCIs that incorporated social media features and targeted tobacco smoking, diet and nutrition, physical activities, or alcohol consumption. The screening and review process was performed by 2 independent researchers.

Results: A total of 5264 articles were screened, and 143 articles describing a total of 134 studies were retained for full review. The majority of studies (70\%) reported positive outcomes, followed by $28 \%$ finding no effects with regard to their respective objectives and hypothesis, and $2 \%$ of the studies found that their interventions had negative outcomes. Few studies reported on the association between the inclusion of social media features and intervention effect. A taxonomy of social media features used in behavioral interventions has been presented with 36 social media features organized under 7 high-level categories. The taxonomy has been used to guide the analysis of this review.

Conclusions: Although social media features are commonly included in DBCIs, there is an acute lack of information with respect to their effect on outcomes and a lack of clear guidance to inform the selection process based on the features' suitability for the different behaviors. The proposed taxonomy along with the set of recommendations included in this review will support future research aimed at isolating and reporting the effects of social media features on DBCIs, cross-study comparisons, and evaluations.
\end{abstract}

(J Med Internet Res 2018;20(2):e20) doi: 10.2196/jmir.8342

\section{KEYWORDS}

systematic review; social media; behavior control; health behavior; behavioral medicine; eHealth 


\section{Introduction}

Supporting positive change in health behavior is a widely explored and active area of research commonly referred to as behavior change intervention (BCI) [1]. With advances in information and communication technologies (ICTs), researchers have developed digital behavior change interventions (DBCIs) [2], in which digital platforms such as the Web are used to deliver interventions targeting individuals whose physical locations may be different from that of the intervention provider, thus expanding the reach of the intervention. Along with this, DBCI presents other benefits such as reducing the financial and human resources usually required as input at such scale and enabling participants to engage with the interventions at times of their own choosing.

\section{Social Media in Digital Behavior Change Interventions}

Using technologies such as the Web and sensor-rich phones potentially brings a tremendous leap toward large-scale BCIs. However, although many interventions focus on working at the individual participant level, an enormous amount of information that individuals share naturally with one another along with the accompanying peer support exchanged are left untapped. The use of social media features may provide new mechanisms to better understand individuals' context and behaviors. These Web-based features enable users of an intervention to communicate or share data in virtual communities. A few examples of social media features are as follows: user profiles, groups, polls, online forums, etc. The features can help enhance the overall effectiveness of DBCIs by encouraging social interactions within interventions, promoting social support, and facilitating the adoption of social norm approaches. Social media features have been shown to be beneficial within intervention as identified in previous research in terms of increased motivation level and engagement with the interventions, for example [3-5].

A recent systematic review, which examined the use of online social networks (OSNs) in health BCIs, identified 10 research studies matching their set of criteria [6]. The use of social media features in DBCIs is an area of research that requires further examination. Two reviews exist that applied different search criteria, which did not seek to capture the full range of social media features included within DBCIs, including online forums, chat rooms, blogs, etc, which are not always defined within OSNs $[7,8]$. Systematic reviews with regard to the use of social media features in DBCIs that have been published tend to target only $1[9,10]$ or 2 [11] out of the 4 behavioral risk factors published by the World Health Organization (WHO) as leading risk factors for global disease burden, which included tobacco smoking, alcohol use, physical inactivity, and diet [12]. This makes it hard to facilitate comparison across behaviors.

\section{Systematic Review of Social Media Inclusion}

This review systematically identifies and analyzes peer-reviewed publications of DBCIs that include social media features or OSNs and target tobacco smoking, diet and nutrition, physical activities, or alcohol consumption. This creates an opportunity to have a better understanding about their effectiveness and how this differs for the various targeted behaviors. Although a taxonomy for the reporting of BCIs that focuses on standardizing definitions of techniques included in them was published [13], a corresponding taxonomy would be beneficial for social media features. Specifically, this paper presents the construction of a taxonomy of social media features, which will help in analysis and also provide guidance for selecting and including these features in interventions targeting specific risk factors. The behavioral outcomes in terms of users' engagement and perceptions with regard to the inclusion of social media features are presented and analyzed. The impact and effectiveness of each of these features are also reported. A set of recommendations based on this review's findings has been included to help researchers who are planning to include social media features in their behavioral interventions.

\section{Methods}

\section{Identification of Studies}

Information sources included literature searches that were conducted in the following health-related and multidisciplinary databases to ensure both the technical and behavioral aspects of interventions could be captured: Web of Science, Scopus, Engineering village, Medline, ERIC, CINAHL, PsycINFO, ProQuest, and Cochrane. Combined variants of relevant terms from the social media and DBCI domains were used to build a search query (eg, common social media terms such as Facebook and forum combined with terms such as online and Web and target behaviors such as diet and smoking). After refinements by 2 independent researchers, the finalized search query (see Multimedia Appendix 1) was used to conduct the searches. The search was conducted on November 30, 2015, with a time range between the year 2000 and the search date.

\section{Screening Process}

The search results were downloaded, combined, and sorted for an initial filtering to remove duplicates. Then, 2 independent reviewers went through separate but identical copies of the result-set of unique entries to flag the nonrelevant ones based on our inclusion and exclusion criteria by going through their titles and abstracts. Differences were then resolved through consultation. The same reviewers conducted a subsequent eligibility screening of the remaining full-text articles.

To be included in the review, studies had to be (1) in the form of published and peer-reviewed full-text articles from conferences and journal papers and (2) targeting at least one of the following modifiable behavioral risk factors published by the WHO: "Tobacco use, physical inactivity, unhealthy diet and the harmful use of alcohol" [12].

No restrictions were placed on sample population used; participants from all age groups (including minors), gender, and health status were eligible for inclusion. Review papers for behavioral interventions that included references to studies matching our selection criteria were manually searched to identify studies that might have been missed in our initial search.

A total of 143 publications were retained for data extraction and analysis as presented in Figure 1 according to the Preferred Reporting Items for Systematic Reviews and Meta-Analyses (PRISMA) guidelines. Out of these, 8 studies were reported 
through more than 1 publication (7 studies with 2 publications each and 1 study with 3 publications). Therefore, 134 studies were analyzed. Among these studies, 74 adopted a randomized controlled trials (RCT) design, with the remaining favoring a mostly experimental approach. However, they all provided valuable insights of social media features in their evaluation and were, therefore, included.

Figure 1. Flow diagram of the studies' inclusion process.

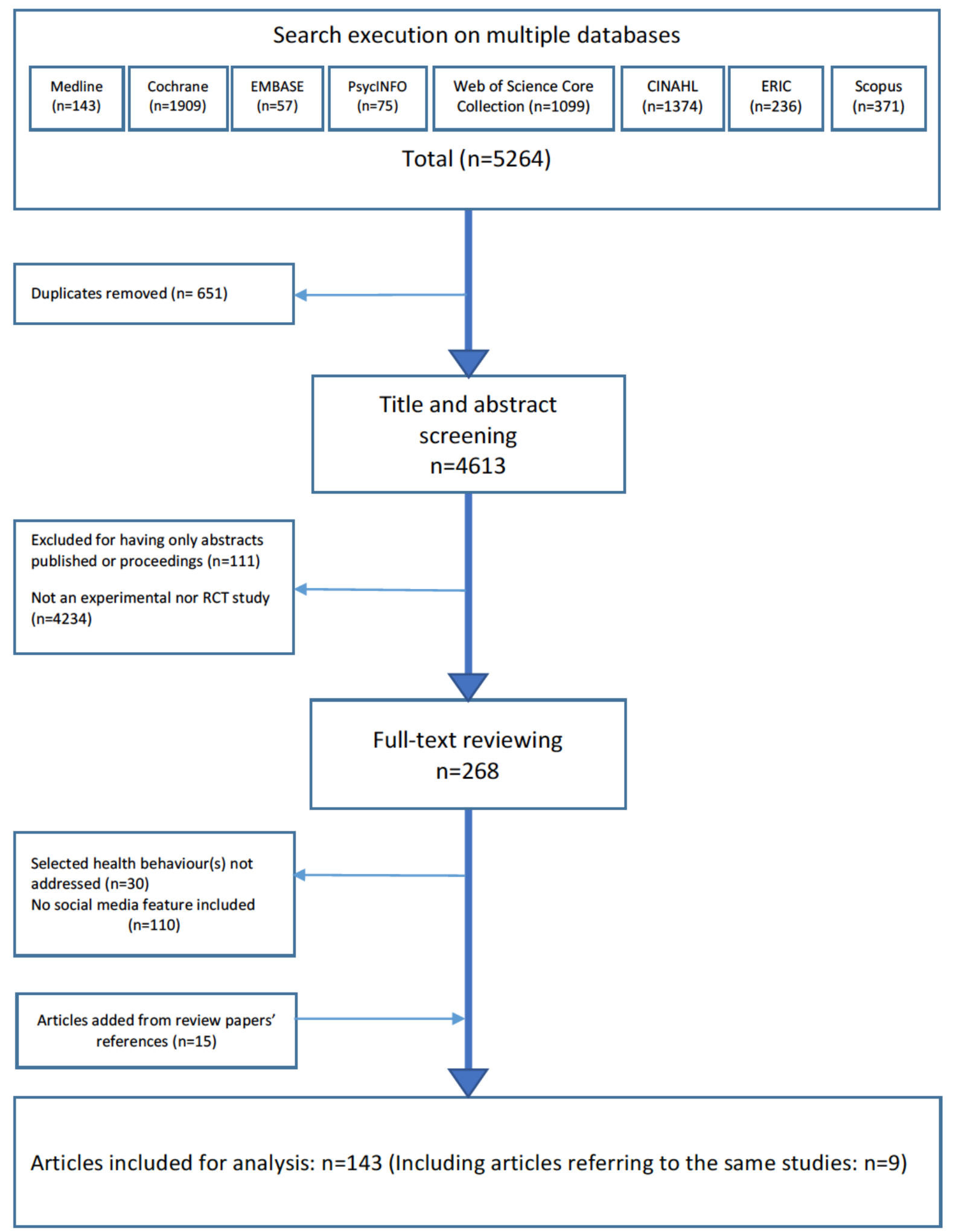




\section{Data Extraction and Analysis}

A data extraction table was used to record key details for each study being reviewed (see Multimedia Appendix 2). Two reviewers were involved in this process. The first one performed the actual extraction, whereas the second reviewer verified the extracted data. The outcome of each of the studies was classified as positive, neutral, or negative. This classification was done by comparing the objective(s) and hypothesis stated for the studies with their reported results and findings. For studies that adopted an RCT design, when their intervention arm(s) were more effective than their control arm(s) by either or both the extent of change in behavior and the number of participants successfully adopting healthier behaviors, they were considered as having a positive outcome. In cases where no significant difference was reported between the intervention and control arms, the studies were considered as having a neutral outcome. Finally, for studies in which the control arm(s) were more effective in improving participants' behavior than the intervention $\operatorname{arm}(\mathrm{s})$, the outcome was classified as negative. However, in the last situation, the reason(s) behind the control group outperforming the intervention arm would require further investigation, which is out of the scope of this review. Similarly, the same methods were adopted for studies with experimental or prepost designs by comparing the initial objective(s) and hypothesis with the studies' findings.

The data table was analyzed for patterns of social media features' inclusion in the different interventions to determine whether there was any correlation with the studies' outcomes. The data were also used to inform the development of the taxonomy of social media features.

\section{Results}

\section{Study Characteristics}

A breakdown of the 134 studies reviewed, categorized by their targeted behaviors, is shown in Table 1. The majority of the studies targeted physical activity, either as a single behavior or in combination with other behaviors such as diet and nutrition. Alcohol consumption was addressed by the fewest number of studies.

\section{Taxonomy of Social Media Features}

An initial prereview literature search was undertaken to identify potential social media features for incorporation in the search query for the review. The data extraction process for the publications reviewed led to the identification of an initial list of 29 social media features, with $70.1 \%$ (94/134) of the studies using more than 1 of these features. An initial set of hierarchical categories was then proposed and compared with one of the closest and related taxonomy published, which was by Michie et al [13]. This was undertaken by the main researcher and was reviewed by an independent researcher. Out of the 16 groups of techniques in Michie et al's taxonomy, 6 of them were found to be relevant to social media features used in behavioral interventions, namely, goals and planning, feedback and monitoring, social support, comparison of behavior, reward and threat, and finally, identity. However, because of the fact that some social media features tended to be in multiple groups of techniques, a new hierarchical categorization better adapted for these features was proposed. This has been reviewed by 2 independent researchers to reach the final version presented in this paper. It is important to note that this taxonomy does not include an exhaustive list of social media features, but instead focused on those that are included in the 134 studies in this review. The list of social media features has been adapted to match the proposed taxonomy, which required in some cases the merging of 2 or more features (eg, blog and testimonial, and experience sharing) or the splitting of specific features into multiple ones (social challenge, contest, or competition). The final version of the taxonomy is presented in Figure 2.

Seven main categories of social media features have been identified, which are described in Table 2. A brief description of each social media feature in the taxonomy is provided in Multimedia Appendix 3.

Table 1. Breakdown of number of studies by addressed behaviors.

\begin{tabular}{ll}
\hline Addressed behaviors & $\mathrm{n}(\%)$ \\
\hline Alcohol consumption & $5(3.7)$ \\
Diet and nutrition & $7(5.2)$ \\
Diet and nutrition + physical activity & $11(8.2)$ \\
Diet and nutrition + physical activity + alcohol consumption & $1(0.7)$ \\
Physical activity & $38(28.4)$ \\
Physical activity + smoking cessation & $1(0.7)$ \\
Smoking cessation & $25(18.7)$ \\
Weight loss or weight maintenance + diet and nutrition & $3(2.2)$ \\
Weight loss or weight maintenance + diet and nutrition + physical activity & $43(32.1)$ \\
Total number of studies analyzed & $134(100.0)$ \\
\hline
\end{tabular}


Figure 2. Taxonomy of social media features.

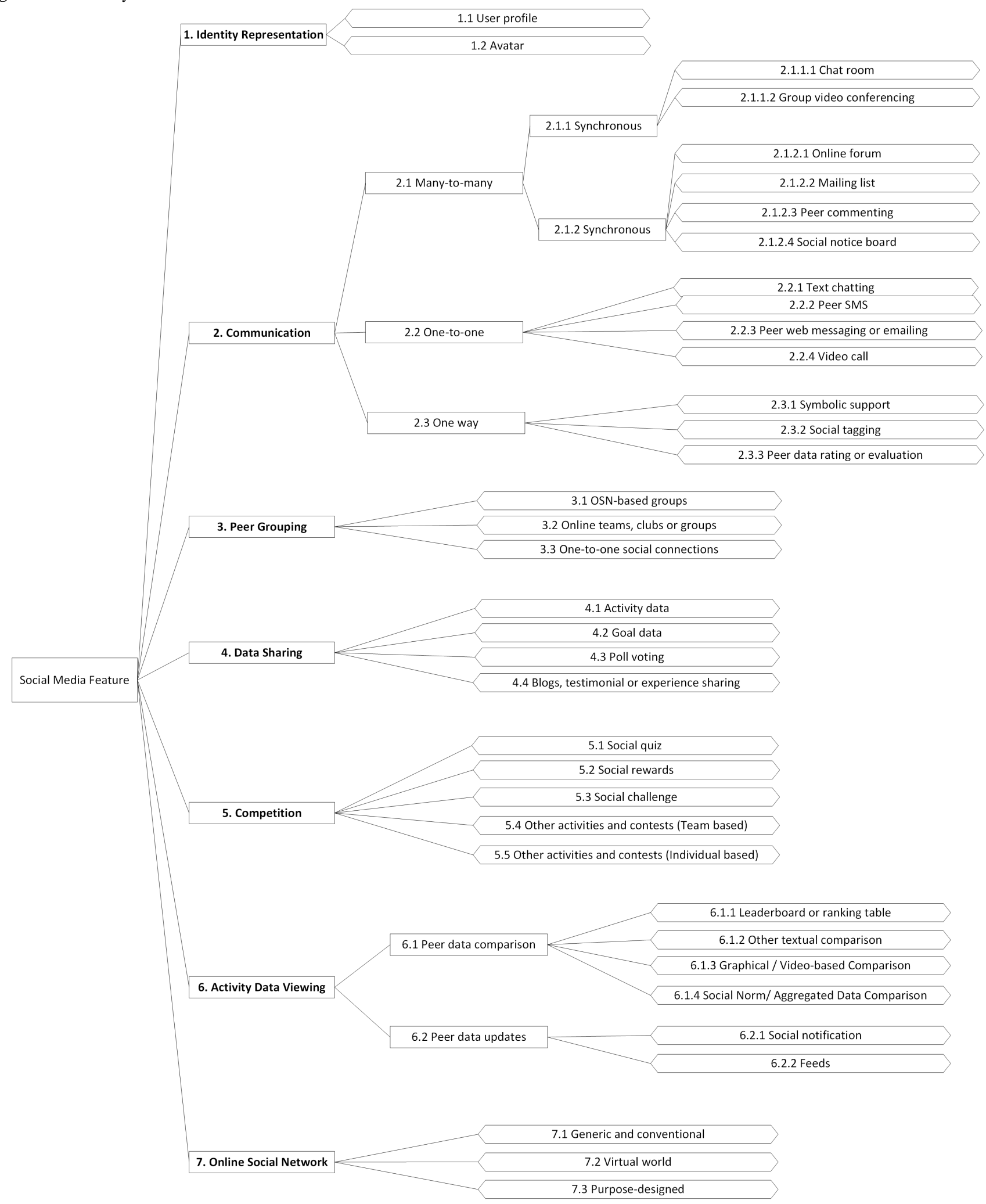


Table 2. Categories of social media features.

\begin{tabular}{|c|c|c|}
\hline Number & Category & Description \\
\hline 1 & Identity representation & $\begin{array}{l}\text { Used to provide information about an individual and his or her activities to peers and are usually customizable } \\
\text { by the participant. This is usually either in the form of user profiles or avatars }\end{array}$ \\
\hline 2 & Communication & $\begin{array}{l}\text { Enable intervention participants to communicate with one another and could be further categorized as many } \\
\text { to many (eg, chat rooms), one to one (eg, peer emailing), and one way (eg, thumbs up or likes) }\end{array}$ \\
\hline \multirow[t]{2}{*}{3} & Peer grouping & $\begin{array}{l}\text { Grouping of participants based on characteristics such as age, geographical locations, or part of the same } \\
\text { intervention arm, while ensuring that they are aware about others in their group and with the possibility to }\end{array}$ \\
\hline & & $\begin{array}{l}\text { have some form of direct or indirect communication. Groups can consist of a minimum of } 2 \text { participants or } \\
\text { OSN-based and non-OSN-based groups with more than } 2 \text { individuals }\end{array}$ \\
\hline 4 & Data sharing & $\begin{array}{l}\text { Enable participants of an intervention to share data about their activity, goals, or experience to either or both } \\
\text { other participants and nonparticipants }\end{array}$ \\
\hline 5 & Competition & $\begin{array}{l}\text { Designed to introduce a competitive aspect in interventions through the use of features that enable participants } \\
\text { to feel motivated while competing against one another (eg, social quiz) }\end{array}$ \\
\hline 6 & Activity data viewing & $\begin{array}{l}\text { Provide access to activity data of peers to participants through either regular updates (feeds and notifications) } \\
\text { on a timely basis or enable them to compare their own data with that of their peers (eg, leaderboards) }\end{array}$ \\
\hline 7 & $\begin{array}{l}\text { Online social network } \\
(\mathrm{OSN})\end{array}$ & $\begin{array}{l}\text { The use of an Internet-based platform for enabling social interaction among intervention participants. OSNs } \\
\text { can be subcategorized as either Generic and Conventional type (Facebook, mySpace, Twitter), Virtual World } \\
\text { (SecondLife), or Purpose Designed (Yahoo Diet Diary, iWell, QuitNet, other intervention-specific proprietary } \\
\text { OSNs). OSNs although being considered as a social media feature, usually act as a container for multiple } \\
\text { other social media features }\end{array}$ \\
\hline
\end{tabular}

${ }^{\mathrm{a} O S N}$ : online social network.

An important aspect to bear in mind when working with this taxonomy is that the different categories and their subcategories are not mutually exclusive and social media features are classified according to their most predominant properties. An example of an overlap between data sharing and peer data updates, where both are about the sharing of data, is that, for the latter, a user would receive updates about other peers without the peers actively involved in the sharing process (shared in an automated fashion), whereas, for the former, the peers would be actively sharing specific data with specific individuals or groups and could possibly have more fine-grained control over the sharing process.

\section{Social Media Features' Inclusion}

Communication-based features were the most prevalent and were included in a majority of studies, as shown in Table 3. Features from the competition, OSN, and identity representation categories were the least prevalent. The other high-level categories were peer grouping, activity data viewing, and data sharing. The inclusion of social media features from the different categories does not appear to differ by specific behaviors targeted. The only anomaly with this trend was for alcohol consumption. Studies with combinations of multiple behaviors were considered for each behavior individually.

The inclusion of specific social media features in studies targeting the different behaviors is presented in Multimedia Appendix 4.

When considering which addressed behaviors had the highest inclusion rate for each social media feature, physical activity and smoking cessation each had 11 highest inclusion rate instances, followed by dieting or nutrition and alcohol consumption with 5 instances each, and finally, 3 instances for weight loss or maintenance. The set of social media features that were the most included ones remained unchanged across all the behaviors considered in this review, except for alcohol consumption. These were online forums, social connections, and user profiles.

Social media features under the communication category remained the most popularly included across all the 5 behaviors considered in this review. Most of the studies included at least one social media feature based on communication, and with a consistent inclusion rate, 6 out of 10 studies in this review have made use of online forums as part of their interventions.

Features from the identity representation category and peer grouping category were more prevalent in interventions that addressed smoking cessation compared with other behaviors, with none of the interventions that targeted alcohol consumption using any of the features from this category.

Physical-activity related interventions were the most likely to include social media features from the competition category through social rewards. However, the highest inclusion rate from this category was below $12 \%$. Although none of the interventions that addressed alcohol consumption included competition-based features, 2 smoking cessation interventions used features from this category, which included social quiz or activities and contests (individual-based) features. 
Table 3. Studies that included social media features from the different categories.

\begin{tabular}{ll}
\hline SMF $^{\mathrm{a}}$ categories & Studies' references \\
\hline Communication & {$[3,5,14-141]$} \\
Peer grouping & {$[3,5,7,8,14,15,19,26,29-32,34,35,38,46,49,50,55,57,58,60,66,67,69,73,76,80,82,83,85,87,89,91,92,97,104-106,110,112$,} \\
& $113,118,121,124,126,127,129,130,133,139-147]$ \\
Data sharing & {$[3,14,19,26,31,32,34,38,41-43,46,49,54-57,59,60,72,73,76,80,81,85,92,97,103-106,110,112,118-120,126,127,133,138,146,148-150]$} \\
Competition & {$[3,5,7,8,15,19,38,39,42,46,49,50,54,57,67,87,91,98,104,109,112,118,133,142,151,152]$} \\
Activity data viewing & {$[3,5,7,8,14,19,26,27,29-32,34,38,39,46,49,50,54,55,57,58,60,66,67,73,76,80-83,85,87,91,92,97,103-105,126,127,129,130,133$,} \\
& $142-145,147-149,151,152]$ \\
Online social network & {$[3,5,14,15,19,26,29-32,35,46,49,55,57,58,60,67,69,76,80,83,85,91,92,97,104,105,114,118,126,129,130,133,138,140,141,143-145]$} \\
Identity representation & {$[3,5,14,15,19,26,29-32,35,38,40,46,49,50,54-58,60,67,76,80,82,83,85,91,92,97,98,104,105,126,129,130,134,140,141]$} \\
\hline
\end{tabular}

${ }^{\mathrm{a}} \mathrm{SMF}$ : social media features.

Table 4. Interventions reported outcomes while including social media features from the different categories.

\begin{tabular}{llllllll}
\hline Study outcome & $\begin{array}{l}\text { Communication, } \\
\mathrm{n}(\%)\end{array}$ & $\begin{array}{l}\text { Peer grouping, } \\
\mathrm{n}(\%)\end{array}$ & $\begin{array}{l}\text { Data sharing, } \\
\mathrm{n}(\%)\end{array}$ & $\begin{array}{l}\text { Competition, } \\
\mathrm{n}(\%)\end{array}$ & $\begin{array}{l}\text { Activity data } \\
\text { viewing, } \mathrm{n}(\%)\end{array}$ & $\begin{array}{l}\text { Online social } \\
\text { network, } \mathrm{n}(\%)\end{array}$ & $\begin{array}{l}\text { Identity representa- } \\
\text { tion, } \mathrm{n}(\%)\end{array}$ \\
\hline $\begin{array}{l}\text { Studies with positive } \\
\text { outcome }\end{array}$ & $88(71.0)$ & $47(84)$ & $40(93)$ & $20(77)$ & $40(80)$ & $31(84)$ & $34(87)$ \\
$\begin{array}{l}\text { Studies with neutral } \\
\text { outcome }\end{array}$ & $33(26.6)$ & $9(16)$ & $2(5)$ & $6(23)$ & $10(20)$ & $6(16)$ & $5(13)$ \\
$\begin{array}{l}\text { Studies with nega- } \\
\text { tive outcome }\end{array}$ & $3(2.4)$ & $0(0)$ & $1(2)$ & $0(0)$ & $0(0)$ & $0(0)$ & $0(0)$
\end{tabular}

For the peer data comparison subcategory of activity data viewing, interventions addressing physical activity were the most likely to include these features compared with other behaviors, with only 1 study in alcohol consumption and another from smoking cessation including a feature from this category.

OSNs of generic and conventional types were most popular in studies addressing weight loss or weight maintenance, followed closely by diet and nutrition and physical activity interventions. On the other hand, virtual worlds were included the most in interventions addressing smoking cessation. Although there was not much difference in the inclusion rate for purpose-designed OSNs for the 4 behaviors, studies that targeted smoking cessation used them the most.

\section{Social Media Features and Behavioral Outcomes}

The majority of studies were classified as having positive outcomes (94/134, 70\%), followed by neutral outcomes (37/134, $28 \%)$ and negative outcomes $(3 / 134,2 \%)$. Table 4 presents an analysis of the prevalence of social features by study outcome.

The majority of studies that included social media features reported positive outcomes, with the lowest percentage being $71 \%$ for the communication category and the highest at $93 \%$ for data sharing. Out of the 134 studies reviewed, only 4 studies reported negative outcomes. This trend persisted consistently across all the 5 behaviors considered, as shown in Table 5.

Studies that included social media features from the data sharing category were more likely to report positive outcomes for all the behaviors considered as compared with features from other categories. For example, one intervention that addressed physical activity, diet and nutrition, and weight loss or weight maintenance enabled participants to use blogs to share their personal experience [26]. In line with this, testimonial sharing was included in several studies addressing smoking cessation $[14,31,32,55]$, which encouraged participants to share their own experience with others. Most of these studies also enabled the sharing of quit-smoking goals among one another. Although in most studies, data sharing through the variety of features under this category was initiated by participants, at least one study [34] addressing physical activity provided a functionality for participants to request others to share their data, which in this case was step counts. Haines-Saah et al [58], who used an OSN-based private group (peer-grouping category) for enabling participants to post photos (Data sharing category), reported gender bias in terms of engagement, whereby female participants tended to share more pictures and remained engaged for a longer period of time.

This was followed by identity representation and OSNs, both of which had significant overlaps due to the fact that OSNs were often used as a container for other social media features, with identity representation consisting of a user profile and avatar often being included. The most prevalent OSNs were QuitNet for studies addressing smoking cessation and Facebook for other behaviors. Studies that included features from the communication category reported higher levels of neutral and negative outcomes across the different behaviors compared with the other categories. Except for features from the communication category, studies addressing smoking cessation all reported positive outcomes (100\%) for the other categories. 
Table 5. Studies addressing different behaviors that reported positive, neutral, or negative outcomes.

\begin{tabular}{|c|c|c|c|c|c|c|c|}
\hline $\begin{array}{l}\text { Studies and their reported } \\
\text { outcomes }\end{array}$ & $\begin{array}{l}\text { Communica- } \\
\text { tion, } \mathrm{n}(\%)\end{array}$ & $\begin{array}{l}\text { Peer grouping, } \\
\mathrm{n}(\%)\end{array}$ & $\begin{array}{l}\text { Data sharing, } \mathrm{n} \\
(\%)\end{array}$ & $\begin{array}{l}\text { Competition, } \mathrm{n} \\
(\%)\end{array}$ & $\begin{array}{l}\text { Activity data } \\
\text { viewing, } \mathrm{n}(\%)\end{array}$ & $\begin{array}{l}\text { Online social } \\
\text { network, n }(\%)\end{array}$ & $\begin{array}{l}\text { Identity Repre- } \\
\text { sentation, } \mathrm{n}(\%)\end{array}$ \\
\hline \multicolumn{8}{|l|}{ Physical activity } \\
\hline Positive & $57(66)$ & $31(79)$ & ${ }^{\mathrm{a}} 24(89)$ & $17(74)$ & $28(76)$ & $19(76)$ & $22(81)$ \\
\hline Neutral & $26(30)$ & $8(21)$ & $2(7)$ & $6(26)$ & $9(24)$ & $6(24)$ & $5(19)$ \\
\hline Negative & $3(3)$ & $0(0)$ & $1(4)$ & $0(0)$ & $0(0)$ & $0(0)$ & $0(0)$ \\
\hline \multicolumn{8}{|l|}{ Diet and nutrition } \\
\hline Positive & $44(71)$ & $19(83)$ & $17(94)$ & $7(70)$ & $15(75)$ & $17(89)$ & $16(89)$ \\
\hline Neutral & $16(26)$ & $4(17)$ & $1(6)$ & $3(30)$ & $5(25)$ & $2(11)$ & $2(11)$ \\
\hline Negative & $2(3)$ & $0(0)$ & $0(0)$ & $0(0)$ & $0(0)$ & $0(0)$ & $0(0)$ \\
\hline \multicolumn{8}{|l|}{ Smoking cessation } \\
\hline Positive & $21(81)$ & $12(100)$ & $11(100)$ & $2(100)$ & $7(100)$ & $8(100)$ & $9(100)$ \\
\hline Neutral & $5(19)$ & $0(0)$ & $0(0)$ & $0(0)$ & $0(0)$ & $0(0)$ & $0(0)$ \\
\hline Negative & $0(0)$ & $0(0)$ & $0(0)$ & $0(0)$ & $0(0)$ & $0(0)$ & $0(0)$ \\
\hline \multicolumn{8}{|l|}{ Alcohol consumption } \\
\hline Positive & $4(80)$ & $1(100)$ & $1(100)$ & $O(0)$ & $1(100)$ & $0(0)$ & $0(0)$ \\
\hline Neutral & $1(20)$ & $0(0)$ & $0(0)$ & $0(0)$ & $0(0)$ & $0(0)$ & $0(0)$ \\
\hline Negative & $0(0)$ & $0(0)$ & $0(0)$ & $0(0)$ & $0(0)$ & $0(0)$ & $0(0)$ \\
\hline \multicolumn{8}{|l|}{$\begin{array}{l}\text { Weight loss or weight } \\
\text { maintenance }\end{array}$} \\
\hline Positive & $33(73)$ & $12(80)$ & $11(92)$ & $5(83)$ & $9(82)$ & $11(85)$ & $10(83)$ \\
\hline Neutral & $10(22)$ & $3(20)$ & $1(8)$ & $1(17)$ & $2(18)$ & $2(15)$ & $2(17)$ \\
\hline Negative & $2(4)$ & $0(0)$ & $0(0)$ & $0(0)$ & $0(0)$ & $0(0)$ & $0(0)$ \\
\hline
\end{tabular}

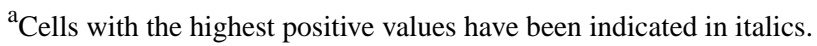

\section{Reported Impact of Social Media Features}

Of the studies reviewed, $72.4 \%$ (97/134) published additional information about social media features that were included within their interventions either or both in their results and discussions sections. However, despite the high percentage, the type and amount of information provided about the social media features varied widely from one study to another, ranging from usage data (eg, frequency a feature was used, number of participants using it), impact-related information (eg, whether the feature had an effect on usage or behavioral outcomes), and participants' perceptions (eg, usefulness, satisfaction, helpfulness, and social support derived). Similarly, the level of details varied from one descriptive sentence (eg, the studies by Block et al and Sternfeld et al [21,22]) to a full paragraph of text providing each social media feature's statistical data and accompanying description (eg, the intervention by Napolitano et al [105]).

None of the studies that explicitly reported on the social media features described any negative impact on the outcome of the interventions. Indeed, $69.1 \%$ of the studies described the outcome of these features in positive terms and reported a range of effects attributed to their usage, such as higher levels of engagement with the interventions, increased perception of usefulness and satisfaction, as well as improvements in addressed behaviors attributed directly to the use of social media features. The remaining studies $(n=30)$ reported either or both low usage $(<50 \%$ of participants using a social media feature) and neutral outcomes.

\section{Usage}

The inclusion of social media features has been reported to be associated with increased user engagement in behavioral interventions.

\section{Communication}

Asynchronous features from the communication category (eg, online forums) were reported to support increases in usage and engagement $[52,79,109,117,119,120]$, whereas studies that included synchronous features (eg, online video and chat rooms) for meetings [16,41,62-65] mostly reported no effect or reduced engagement when compared with controls (face-to-face). Interestingly, it was reported that female participants tended to engage in online group discussions more than their male counterparts [69]. Online forums have also been found to encourage usage over longer periods [109].

\section{Peer Grouping and Data Sharing}

Engagement was also found to be gender-biased in an OSN-based private group where participants could post photos, with females sharing more pictures and remaining engaged for 
longer periods of time [58]. Social connections were found to contribute toward motivating participants to engage more with the interventions $[3,7,50,146]$. Similar findings were also reported for peer-led support, leading to an increase in the frequency of participants visiting an intervention's website [108].

Along with peer grouping-based features, interventions commonly included data sharing features $[50,58,60]$. The inclusion of polls was found to promote engagement the most as compared with other types of textual or graphical data [60], whereas the ability to create social connections to share each other's activity data [50] or the use of an OSN-based private group to share photos [58] also produced high levels of engagement among their participants.

\section{Competition and Activity Data Viewing}

Competitive elements such as social challenges in interventions addressing physical activity were also found to promote engagement [7]. Linked with the competitiveness, the use of Leader Boards or Ranking tables from the Activity Data Viewing category caused participants who were interested with their ranking to access the intervention's application more often [152]. Similarly, the inclusion of graphical-based comparisons [50] led to increases in user engagement.

\section{Online Social Networks}

It was reported that participants spent more time using an intervention that included an OSN platform [94]. Indeed, higher levels of engagements from participants were observed when OSNs were included along with their accompanying social media features $[26,92]$. However, this had no effect on attrition or retention rates $[26,60]$.

\section{Participants' Perceptions: Social Support, Helpfulness, Satisfaction, and Motivation}

Social media features are usually associated with enhanced social support and motivation perceived by participants.

Most of these studies included features from the communication category such as online forums and chat rooms. Although some of those that included online forums reported positive perceptions of social support among participants [40,72,98], there was also the possibility of no change [114] and even a demotivating effect based on content quality shared by participants [84,114]. Forums were often found to be useful or helpful by a majority of participants $[15,27,40,51]$, although in some studies this dropped to below $50 \%$ of participants $[42,93,95]$. The lower percentages were attributed to a "lack of critical mass" in the number of participants engaging actively in the forums to change others' perception positively [93] or could be based on participants' preferring personal email counseling compared with peer-to-peer support from online forums [86]. It was reported that participants actively sought social support from peers through chat rooms and derived positive perception of social support $[68,98]$, but this perception was lower as compared with in-person group meetings [65]. Other features that were associated with positively enhancing participants' perception were group video chatting [41], mailing list [68], peer commenting [66], peer emailing [98], peer SMS text messages (short message service, SMS) [106,113,127], text chatting (one-to-one) [83], and symbolic support [66].

Peer grouping features were also found to help improve social support perceptions. Participants with access to these features had higher levels of social support coping [38,72,87,106,113]. However, this could also be attributed to participants feeling pressured in meeting goals or enjoying recognition and encouragements from peers $[34,38,104]$. Similar to content quality affecting motivation, social connections could have a demotivating factor in cases where the social support originates from better-performing peers [73].

Data sharing and peer data viewing had positive effects on perception of social support and motivation, especially when peers provide feedback [34,56,72,87,104,106,146]. However, data sharing was not always attributed with enhanced social support, with reported mixed effects when support originated from nonparticipants (external supporters) and their inability in constructing motivating messages [127] or possible concerns from participants about the usefulness to peers for the data being shared [42,149]. A positive correlation between the level of social support and the activeness of participants in data-sharing activities for an intervention addressing diet and nutrition was reported [66].

The inclusion of competition-based features in interventions was more likely to have a positive effect on participants' perception of social support motivation levels in an intervention that addressed physical activity as at least one of its behaviors addressed [50,98], but this was not always the case [104]. Although rarely used in addiction-related behaviors, a feature from the Competition category, in the form of a quit-smoking contest in an intervention addressing Smoking Cessation, was perceived as "somewhat valuable" and had a low usage rate $(35.3 \%)$ [104].

The only study among the reviewed articles to report on the impact on social support associated with the inclusion of $O S N$ in behavioral interventions found no change in social support perception [114]. However, OSNs were among the most-reported features for perceived usefulness $[15,26,58,60,67]$. Although at least two interventions $[15,26]$ used purpose-designed OSNs, Facebook was used as the OSN in the other interventions [58,60,67]. This perception of usefulness could likely be also linked to the prevalent popularity of Facebook as a generic OSN platform among individual users. Another interesting finding was the increased credibility perception among participants when a virtual world-type OSN with a recreated classroom along with an instructor avatar was used in an intervention addressing diet and nutrition and physical activity [35].

\section{Behavioral Outcome}

A total of 29 studies reported on the effectiveness of some of the social media features included in their interventions in contributing to change participants' behaviors (see Multimedia Appendix 5). These features were from 5 of high-level categories in our taxonomy, namely, identity representation, communication, peer grouping, activity data viewing, and OSN. 
Communication-based social media features included in behavioral interventions were among the most reported for their effectiveness in modifying behaviors. Interactions among participants through asynchronous features such as forums were reported to have led to behavior change in at least four studies $[75,79,108,135,136]$ that addressed a combination of physical activity, diet and nutrition, and weight loss. However, in at least one study, this change was minimal and only found among female participants [75]. Forums were among the most reported in studies addressing smoking cessation with regard to its effect in changing participants' behavior positively [31,32], although in at least one case no effect was found [117]. Chat rooms, enabling synchronous communication among participants were also reported to effectively modify behavior in some studies. Among interventions that addressed physical activity, diet and nutrition, and weight loss or weight maintenance, chat rooms were found to be effective in 2 interventions [76,135,136], whereas no effects were observed in others [62-64]. Smoking Cessation interventions could also benefit from their effectiveness, as it has been reported that participants with access to chat rooms were more likely to report abstaining from smoking [141]. One-to-one communication-based features have been reported to increase abstinence rates [14,55], increase physical activity, and lead to weight loss [57].

The use of peer grouping-based features was found to result in a number of positive outcomes, such as weight loss among studies addressing weight loss or weight maintenance, diet and nutrition, and physical activity $[5,8,76,118,129]$, increase in activity levels for studies that addressed only physical activity $[50,73,81,82]$, and also increase in the likeliness of quitting smoking in smoking cessation interventions [31,38,55].

Activity data viewing was also reported to have a positive impact on behavior change among studies addressing physical activity. Social interactions through games and allowing viewing of peers' performance $[46,133]$ led to increases in physical activity levels.

OSNS used as part of behavioral interventions were also associated with positive behavior change, especially for weight loss [57,76,118,143-145], although this was not always the case [26]. All these studies addressed multiple behaviors, namely, physical activity, diet and nutrition, and weight loss or weight maintenance. Improvements in dietary awareness were also attributed to the use of OSNs [85]. OSNs that included user profiles were also found to encourage participants to smoke less and cause an increase in intentions to quit $[140,141]$.

\section{Discussion}

\section{Principal Findings}

This review found that the majority of studies targeted either physical activity or a combination of behaviors that included physical activity (eg, physical activity, diet and nutrition, and weight loss or weight maintenance). The use of a specific social media feature in interventions addressing such combinations could be potentially risky in certain circumstances, such as a specific social media feature being found to highly encourage an individual to improve a particular behavioral aspect when that behavior is targeted as a single one, but in an intervention combining a second behavior, its effectiveness might be nullified or even create an opposite outcome. This review has not analyzed this aspect in more detail. However, it would be desirable to investigate these effects further.

Physical activity and smoking cessation interventions had the highest prevalence of social media features. Among these features, however, some were consistently more popularly included than others across all the different behaviors considered. Most of the behavioral interventions that included social media features reported positive (>70\%) outcomes with respect to their set of objectives and hypothesis. Interventions that included social media features from the data sharing category had the highest positive outcome percentages $(>88.9 \%)$. The main effects identified to be associated with the inclusion of social media features in behavioral interventions were about usage or engagement of participants; enhanced perception of social support, helpfulness, satisfaction, and motivation; and lastly, behavioral outcome.

It is possible that social media features were found to be more prevalent in physical activity interventions because features that draw on social behavior change techniques are more relevant to this behavior. This is in line with and adds to the findings of McCully et al's [153] survey that reported an increasing viability for using the Internet as a platform for delivering behavioral interventions on large scales. However, it should be pointed out that in most of the reviewed studies, their outcomes were not always explicitly attributed to the impact of the social media features that were included as was also reported in Chang et al's review [9].

The studies reviewed used nonstandard ways of reporting on the social media features by using different names to refer to the same feature and with varying levels of details. For example, online forums were also referred to as messaging board, bulletin board, discussion forum, discussion board, etc. In terms of description, these forums were sometimes moderated by intervention counselors, but not all studies described whether these features were moderated or the extent that counselors were involved in the group discussions. Some studies made use of generic online social networking sites such as Facebook and QuitNet, whereby a large number social features were available to the intervention participants without the researchers necessarily describing them; these features were however included in our analysis. These issues closely relate to the justifications put forward by Michie et al [13] that led to the proposal of a taxonomy for the reporting of BCIs. Without detailed and standardized description, it is not possible to draw comparisons across different studies on the use and impact of social media features. The taxonomy of social media features proposed from this review can support future research by informing more standardized and detailed descriptions that will facilitate cross-study comparison.

Our review identified that similar social media features (eg, online forums) were associated with positive outcomes across different behaviors. This suggests that although mostly prevalent in physical activity interventions, social media features might be relevant for a variety of health issues. However, this could 
also be the result of intervention designers including these features without enough consideration about their suitability and effectiveness on users for the different types of behaviors addressed and could, instead, be more focused on maximizing functionalities in their interventions. Therefore, there is a strong justification to empirically test the suitability and impact of including social media features in behavioral interventions.

Three main areas were identified with regard to the effects of social media features on users, namely, usage, participants' perception, and behavioral outcome. These effects may be attributed to the social influence element of these features reported in previous research $[3,4]$ that found a positive impact in sustaining behavior change. A number of studies reported that the inclusion of social media features increased user engagement in behavioral interventions, and in at least one study, higher levels of sustained user engagement through interaction with multiple social media features was reported [49]. However, when compared with face-to-face alternatives, social media features were found to produce lower levels of engagement. Among the studies that reported the perceived usefulness or helpfulness, or sense of enjoyment and satisfaction of participants when using social media features included in interventions, more than half referred to features from the communication category, more specifically, online forums. Interestingly, in most cases, participants with access to these features felt pressured, motivated, or felt both to achieve goals, contrary to the findings of Dennison et al [154] that reported some degree of reluctance and feeling of embarrassment when participants' data were shared among peers. However, social support originating from better-performing peers [73] or in the form of poor support content quality from peers [84,114] did have a demotivating effect in a few studies reviewed. Although often assumed by researchers that social media features could result in lowering of attrition rate, this effect was minimal, with only one study [109] reporting an increase in likeliness for participants to complete an intervention, whereas 2 other studies reported finding no such effect $[26,60]$. In terms of social media features affecting behavioral outcome, our analysis found that the most effective features were communication-based, and more specifically, asynchronous ones (eg, online forums). Indeed, features from this subcategory of communication are known to provide more direct social support either from peers or trained professionals interacting with users on a one-to-one or one-to-many basis. This in turn can have an impact on behavioral outcomes $[155,156]$.

The low level of focus on privacy based on the limited amount of information provided by the studies reviewed regarding this aspect associated with the sharing and peer viewing of participants' data is an area that requires further attention. Although privacy might not have been an issue where the intervention's data were accessible only to their respective users and their therapists, social media features unlock the potential of data being shared among peers. Another potential challenge of including social media features was the associated cost for moderating shared data, but this was explicitly mentioned by only 1 study [125], which reported that moderation of the online discussion groups (online forums) was the most significant cost of their study.

\section{Limitations and Strengths of the Review}

Among the reviewed studies, there was a lack of information reported on the social media features included and their impact on whether the behaviors addressed were affected directly or indirectly by them. This was in line with Michie et al [13], who found that BCIs with poor descriptions in their research protocols and study reports made them challenging to evaluate their effectiveness and to replicate.

This review included studies from the year 2000 as social media really started gaining popularity from around then. Although it is a fact that there have been a lot of new technologies and changes in the field of ICT, including social media, most basic concepts are still being used, although often adapted to match the current level of technology. Therefore, the social media features included in those studies are still relevant. Accordingly, diligent care must be taken when interpreting this review's findings in the current context. For example, results from the use of social media in recent years would be different from that of the previous decade because of the ways that they are used through different types of devices and interfaces. With our taxonomy, however, future extensions will be possible and help researchers to analyze and compare the evolvement of social media features in behavioral interventions.

This work has adopted a systematic approach for reviewing behavioral interventions, which included social media features across a wide range of behaviors, which has the potential to be used as a foundation for future research in the area. Along with the review, a taxonomy for categorizing social media features has also been presented. The taxonomy does not consist of an exhaustive list of social media features but rather focuses on those that were included in the reviewed studies.

\section{Future Work}

As this is the first attempt at producing a taxonomy for social media features included in behavioral interventions, it is expected that continued refinement will be carried out for standardizing the names and descriptions of the different categories and features in concert with researchers from both Social Science and Computer Science. More research needs to be carried out to find ways for isolating the effects of social media features on intervention users, as this review has found that many studies do not report on these aspects clearly. The complete dataset of studies reviewed consisting of their different attributes such as social media features used, sample size, and behavior(s) addressed has been included in Multimedia Appendix 2.

\section{Recommendations}

This review has found that although social media features are being widely included in behavioral interventions, little research-based evidence of their effectiveness in modifying behaviors exist. There appears to be tendency to use these features based on convenience and popularity rather than their suitability for specific behaviors. We are, therefore, proposing a set of recommendations aimed at researchers and intervention designers to help evaluate and maximize the effectiveness of social media features on behavioral intervention participants. 
First, develop and use a uniform and well-defined labeling scheme for social media features with the help of the taxonomy presented in this review. This will greatly facilitate future research work attempting to identify social media features included in behavioral interventions for comparison and reviewing.

Second, better design of studies capable of isolating, describing, and evaluating the impact of including social media features on participants and on the interventions' overall outcomes, both qualitatively and quantitatively, while ensuring the following aspects are covered: impact of social media features included in behavioral interventions on usage, perception of social support, helpfulness and satisfaction, attrition, and credibility. As reported in this review, the positive or negative impact for the different studies included was quite subjective, and therefore, they could only be cross-evaluated superficially. Should future studies publish sufficient quantitative data as part of their results, effects size could then be used as a selection criteria for systematic reviews.

Third, conduct more research focused on user's experience of social media features and factors such as privacy and cost in their use to understand how they can best be implemented. A user-centered design approach aimed at ensuring that any concerns from the users' point of view are taken on board from an early stage could be considered. As a result, this could potentially increase users' engagement with the social media features.

\section{Conclusions}

It was found that a majority of studies in this review reported positive outcomes with respect to their objectives and hypothesis. A new taxonomy of social media features used in behavioral interventions has been developed that will support researchers and intervention designers in comparing social media features and guiding their future inclusion in behavioral interventions with better consistency. Social media features were reported to increase usage; enhance perceived levels of social support, motivation, and feeling of satisfaction; and also having a direct effect in behavioral outcome. The main concerns identified with respect to the inclusion of social media features in behavioral interventions were, first, an underreported methodical selection process based on their suitability for specific behaviors and other contextual elements. Another issue uncovered was the nonstandardized way to identify and describe social media features and their effects on intervention users. Moreover, little information has been published with respect to the privacy and cost issues associated with social media features' inclusion in behavioral interventions. Therefore, more research on these aspects has been recommended.

\section{Conflicts of Interest}

None declared.

\section{Multimedia Appendix 1}

Search query construction.

[PDF File (Adobe PDF File), 17KB-Multimedia Appendix 1]

\section{Multimedia Appendix 2}

Data table extracted from studies reviewed.

[XLSX File (Microsoft Excel File), 178KB-Multimedia Appendix 2]

\section{Multimedia Appendix 3}

Social media features' description.

[PDF File (Adobe PDF File), 39KB-Multimedia Appendix 3]

\section{Multimedia Appendix 4}

Inclusion of specific social media features by behavior.

[PDF File (Adobe PDF File), 84KB-Multimedia Appendix 4]

\section{Multimedia Appendix 5}

Social media features leading to behavioral change.

[PDF File (Adobe PDF File), 179KB-Multimedia Appendix 5]

\section{References}

1. Yardley L, Choudhury T, Patrick K, Michie S. Current issues and future directions for research into digital behavior change interventions. Am J Prev Med 2016 Nov;51(5):814-815. [doi: 10.1016/j.amepre.2016.07.019] [Medline: 27745680] 
2. Lathia N, Pejovic V, Rachuri KK, Mascolo C, Musolesi M, Rentfrow PJ. martphones for large-scale behavior change interventions. IEEE Pervasive Comput 2013 Jul;12(3):66-73. [doi: 10.1109/MPRV.2013.56]

3. Poirier J, Cobb NK. Social influence as a driver of engagement in a web-based health intervention. J Med Internet Res 2012 Feb 22;14(1):e36 [FREE Full text] [doi: 10.2196/jmir.1957] [Medline: 22356829]

4. Zemin C, Keeling D. Maintaining long-term behaviour change: a role for informal online social support? In: Proceedings of the IADIS International Conferences. 2010 Jul 01 Presented at: IADIS Multi Conference on Computer Science and Information Systems (MCCSIS 2010); 01 July, 2010; Freiburg p. 283-286.

5. Ma X, Chen G, Xiao J. Analysis of an online health social network. New York, NY, USA: ACM; 2010 Presented at: Proceedings of the 1st ACM International Health Informatics Symposium; 2010; Arlington, Virginia, USA p. $297-306$ URL: http://doi.acm.org/10.1145/1882992.1883035 [doi: 10.1145/1882992.1883035]

6. Maher CA, Lewis LK, Ferrar K, Marshall S, De Bourdeaudhuij I, Vandelanotte C. Are health behavior change interventions that use online social networks effective? A systematic review. J Med Internet Res 2014 Feb 14;16(2):e40 [FREE Full text] [doi: 10.2196/jmir.2952] [Medline: 24550083]

7. Ahtinen A, Huuskonen P, Häkkilä J. Let's All Get Up and Walk to the North Pole: Design and Evaluation of a Mobile Wellness Application. 2010 Presented at: The 6th Nordic Conference on Human-Computer Interaction: Extending Boundaries; 2010; Reykjavik, Iceland p. 3-12. [doi: 10.1145/1868914.1868920]

8. Leahey TM, Kumar R, Weinberg BM, Wing RR. Teammates and social influence affect weight loss outcomes in a team-based weight loss competition. Obesity (Silver Spring) 2012 Jul;20(7):1413-1418 [FREE Full text] [doi: 10.1038/oby.2012.18] [Medline: 22310234]

9. Chang T, Chopra V, Zhang C, Woolford SJ. The role of social media in online weight management: systematic review. J Med Internet Res 2013 Nov 28;15(11):e262 [FREE Full text] [doi: 10.2196/jmir.2852] [Medline: 24287455]

10. Joseph R, Durant NH, Benitez TJ, Pekmezi DW. Internet-based physical activity interventions. Am J Lifestyle Med 2014 Jan;8(1):42-68 [FREE Full text] [doi: 10.1177/1559827613498059] [Medline: 25045343]

11. Lehto T, Oinas-Kukkonen H. Persuasive features in web-based alcohol and smoking interventions: a systematic review of the literature. J Med Internet Res 2011 Jul 22;13(3):e46 [FREE Full text] [doi: 10.2196/jmir.1559] [Medline: 21795238]

12. Global Health Observatory (GHO) data : Risk factors. WHO. Risk factors URL: http://www.who.int/gho/ncd/risk factors/ en/ [accessed 2017-03-07] [WebCite Cache ID 6rgetIMNE]

13. Michie S, Richardson M, Johnston M, Abraham C, Francis J, Hardeman W, et al. The behavior change technique taxonomy (v1) of 93 hierarchically clustered techniques: building an international consensus for the reporting of behavior change interventions. Ann Behav Med 2013 Aug;46(1):81-95. [doi: 10.1007/s12160-013-9486-6] [Medline: 23512568]

14. An LC, Schillo BA, Saul JE, Wendling AH, Klatt CM, Berg CJ, et al. Utilization of smoking cessation informational, interactive, and online community resources as predictors of abstinence: cohort study. J Med Internet Res 2008 Dec 20;10(5):e55 [FREE Full text] [doi: 10.2196/jmir.1018] [Medline: 19103587]

15. Antypas K, Wangberg SC. An Internet- and mobile-based tailored intervention to enhance maintenance of physical activity after cardiac rehabilitation: short-term results of a randomized controlled trial. J Med Internet Res 2014 Mar 11;16(3):e77 [FREE Full text] [doi: 10.2196/jmir.3132] [Medline: 24618349]

16. Azar KM, Aurora M, Wang EJ, Muzaffar A, Pressman A, Palaniappan LP. Virtual small groups for weight management: an innovative delivery mechanism for evidence-based lifestyle interventions among obese men. Transl Behav Med 2015 Mar;5(1):37-44 [FREE Full text] [doi: 10.1007/s13142-014-0296-6] [Medline: 25729451]

17. Bennett GG, Herring SJ, Puleo E, Stein EK, Emmons KM, Gillman MW. Web-based weight loss in primary care: a randomized controlled trial. Obesity (Silver Spring) 2010 Feb;18(2):308-313 [FREE Full text] [doi: 10.1038/oby.2009.242] [Medline: 19696764$]$

18. Bersamin M, Paschall MJ, Fearnow-Kenney M, Wyrick D. Effectiveness of a Web-based alcohol-misuse and harm-prevention course among high- and low-risk students. J Am Coll Health 2007;55(4):247-254. [doi: 10.3200/JACH.55.4.247-254] [Medline: 17319331$]$

19. Bielik P, Tomlein M, Krátky P, Mitrík Š, Barla M, Bieliková M. Move2Play: an innovative approach to encouraging people to be more physically active. In: Proceedings of the 2nd ACM SIGHIT International Health Informatics Symposium. 2012 Jan 28 Presented at: International Health Informatics Symposium; 2012; Miami, Florida, USA p. 61-70. [doi: $10.1145 / 2110363.2110374]$

20. Binks M, van Mierlo T. Utilization patterns and user characteristics of an ad libitum Internet weight loss program. J Med Internet Res 2010 Mar 29;12(1):e9 [FREE Full text] [doi: 10.2196/jmir.1347] [Medline: 20350926]

21. Block G, Sternfeld B, Block CH, Block TJ, Norris J, Hopkins D, et al. Development of Alive! (A Lifestyle Intervention Via Email), and its effect on health-related quality of life, presenteeism, and other behavioral outcomes: randomized controlled trial. J Med Internet Res 2008 Nov 19;10(4):e43 [FREE Full text] [doi: 10.2196/jmir.1112] [Medline: 19019818]

22. Sternfeld B, Block C, Quesenberry JC, Block TJ, Husson G, Norris JC, et al. Improving diet and physical activity with ALIVE: a worksite randomized trial. Am J Prev Med 2009 Jun;36(6):475-483. [doi: 10.1016/j.amepre.2009.01.036] [Medline: 19460655]

23. Booth AO, Nowson CA, Matters H. Evaluation of an interactive, internet-based weight loss program: a pilot study. Health Educ Res 2008 Jun;23(3):371-381. [doi: 10.1093/her/cyn007] [Medline: 18349032] 
24. Bosak KA, Yates B, Pozehl B. Feasibility of an internet physical activity intervention. West J Nurs Res 2009 Aug;31(5):648-661. [doi: 10.1177/0193945909334433] [Medline: 19420280]

25. Bosak KA, Yates B, Pozehl B. Effects of an Internet physical activity intervention in adults with metabolic syndrome. West J Nurs Res 2010 Feb;32(1):5-22. [doi: 10.1177/0193945909333889] [Medline: 19357421]

26. Brindal E, Freyne J, Saunders I, Berkovsky S, Smith G, Noakes M. Features predicting weight loss in overweight or obese participants in a web-based intervention: randomized trial. J Med Internet Res 2012 Dec 12;14(6):e173 [FREE Full text] [doi: 10.2196/jmir.2156] [Medline: 23234759]

27. Carr LJ, Dunsiger SI, Lewis B, Ciccolo JT, Hartman S, Bock B, et al. Randomized controlled trial testing an internet physical activity intervention for sedentary adults. Health Psychol 2013 Mar;32(3):328-336 [FREE Full text] [doi: 10.1037/a0028962] [Medline: 22823069]

28. Carter MC, Burley VJ, Nykjaer C, Cade JE. Adherence to a smartphone application for weight loss compared to website and paper diary: pilot randomized controlled trial. J Med Internet Res 2013 Apr 15;15(4):e32 [FREE Full text] [doi: 10.2196/jmir.2283] [Medline: 23587561]

29. Cavallo DN, Tate DF, Ries AV, Brown JD, DeVellis RF, Ammerman AS. A social media-based physical activity intervention: a randomized controlled trial. Am J Prev Med 2012 Nov;43(5):527-532 [FREE Full text] [doi: 10.1016/j.amepre.2012.07.019] [Medline: 23079176]

30. Cavallo DN, Brown JD, Tate DF, DeVellis RF, Zimmer C, Ammerman AS. The role of companionship, esteem, and informational support in explaining physical activity among young women in an online social network intervention. J Behav Med 2014 Oct;37(5):955-966 [FREE Full text] [doi: 10.1007/s10865-013-9534-5] [Medline: 24081454]

31. Cobb NK, Graham AL, Bock BC, Papandonatos G, Abrams DB. Initial evaluation of a real-world Internet smoking cessation system. Nicotine Tob Res 2005 Apr;7(2):207-216 [FREE Full text] [doi: 10.1080/14622200500055319] [Medline: 16036277]

32. Cobb NK, Mays D, Graham AL. Sentiment analysis to determine the impact of online messages on smokers' choices to use varenicline. J Natl Cancer Inst Monogr 2013 Dec;2013(47):224-230. [doi: 10.1093/jncimonographs/lgt020] [Medline: 24395996]

33. Collins CE, Morgan PJ, Jones P, Fletcher K, Martin J, Aguiar EJ, et al. A 12-week commercial web-based weight-loss program for overweight and obese adults: randomized controlled trial comparing basic versus enhanced features. J Med Internet Res 2012 Apr 25;14(2):e57 [FREE Full text] [doi: 10.2196/jmir.1980] [Medline: 22555246]

34. Consolvo S, Everitt K, Smith I, Landay JA. Design requirements for technologies that encourage physical activity. New York, NY, USA: ACM Press; 2006 Presented at: Proceedings of the SIGCHI conference on Human Factors in computing systems - CHI '06; 2006; Montreal, Quebec, Canada. [doi: 10.1145/1124772.1124840]

35. Cowdery JE, Kindred J, Michalakis A, Suggs LS. Promoting health in a virtual world: impressions of health communication messages delivered in second life. First Monday 2011;16(9):14. [doi: 10.5210/fm.v16i9.2857]

36. Cussler EC, Teixeira PJ, Going SB, Houtkooper LB, Metcalfe LL, Blew RM, et al. Maintenance of weight loss in overweight middle-aged women through the Internet. Obesity (Silver Spring) 2008 May;16(5):1052-1060 [FREE Full text] [doi: 10.1038/oby.2008.19] [Medline: 18309301]

37. Danaher BG, Smolkowski K, Seeley JR, Severson HH. Mediators of a successful web-based smokeless tobacco cessation program. Addiction 2008 Oct;103(10):1706-1712 [FREE Full text] [doi: 10.1111/j.1360-0443.2008.02295.x] [Medline: $\underline{18715238}]$

38. Davies C, Corry K, Van Itallie A, Vandelanotte C, Caperchione C, Mummery WK. Prospective associations between intervention components and website engagement in a publicly available physical activity website: the case of 10,000 Steps Australia. J Med Internet Res 2012 Jan 11;14(1):e4 [FREE Full text] [doi: 10.2196/jmir.1792] [Medline: 22260810]

39. DeBar L, Dickerson J, Clarke G, Stevens VJ, Ritenbaugh C, Aickin M. Using a website to build community and enhance outcomes in a group, multi-component intervention promoting healthy diet and exercise in adolescents. J Pediatr Psychol 2009 Jun;34(5):539-550 [FREE Full text] [doi: 10.1093/jpepsy/jsn126] [Medline: 19091807]

40. Doyle AC, Goldschmidt A, Huang C, Winzelberg AJ, Taylor CB, Wilfley DE. Reduction of overweight and eating disorder symptoms via the Internet in adolescents: a randomized controlled trial. J Adolesc Health 2008 Aug;43(2):172-179 [FREE Full text] [doi: 10.1016/j.jadohealth.2008.01.011] [Medline: 18639791]

41. Ehlers DK, Huberty JL, de Vreede GJ. Can an evidence-based book club intervention delivered via a tablet computer improve physical activity in middle-aged women? Telemed J E Health 2015 Feb;21(2):125-131. [doi: 10.1089/tmj.2013.0360] [Medline: 25526014]

42. Escoffery C, McCormick L, Bateman K. Development and process evaluation of a web-based smoking cessation program for college smokers: innovative tool for education. Patient Educ Couns 2004 May;53(2):217-225. [doi: 10.1016/S0738-3991(03)00163-0] [Medline: 15140462]

43. Etter JF. Comparing the efficacy of two Internet-based, computer-tailored smoking cessation programs: a randomized trial. J Med Internet Res 2005 Mar 08;7(1):e2 [FREE Full text] [doi: 10.2196/jmir.7.1.e2] [Medline: 15829474]

44. Ferney SL, Marshall AL, Eakin EG, Owen N. Randomized trial of a neighborhood environment-focused physical activity website intervention. Prev Med 2009;48(2):144-150. [doi: 10.1016/j.ypmed.2008.10.022]

45. Finfgeld-Connett D, Madsen R. Web-Based Treatment of Alcohol Problems Among Rural Women. J Psychosoc Nurs Ment Health Serv 2008 Sep 01;46(9):46-53. [doi: 10.3928/02793695-20080901-05] 
46. Foster D, Linehan C, Kirman B, Lawson S, James G. Motivating physical activity at work: using persuasive social media for competitive step counting. New York, NY, USA: ACM; 2010 Presented at: Proceedings of the 14th International Academic MindTrek Conferencenvisioning Future Media Environments; Oct 2010; Tampere, Finland p. 111-116. [doi: 10.1145/1930488.1930510]

47. Free C, Knight R, Robertson S, Whittaker R, Edwards P, Zhou W, et al. Smoking cessation support delivered via mobile phone text messaging (txt2stop): a single-blind, randomised trial. Lancet 2011 Jul;378(9785):49-55. [doi: 10.1016/S0140-6736(11)60701-0]

48. Frenn M, Malin S, Brown RL, Greer Y, Fox J, Greer J, et al. Changing the tide: an Internet/video exercise and low-fat diet intervention with middle-school students. Appl Nurs Res 2005 Feb;18(1):13-21. [doi: 10.1016/j.apnr.2004.04.003] [Medline: 15812731]

49. Freyne J, Berkovsky S, Kimani S, Baghaei N, Brindal E. Improving health information access through social networking. 2010 Presented at: 23rd IEEE International Symposium on Computer-Based Medical Systems, CBMS; Oct 12-15, 2010; Perth p. 334-339. [doi: 10.1109/CBMS.2010.6042666]

50. Fujiki Y, Kazakos K, Puri C, Buddharaju P, Pavlidis I, Levine J. NEAT-o-Games. Comput Entertain 2008 Jul 01;6(2):1. [doi: $10.1145 / 1371216.1371224]$

51. Gala S, Pesek F, Murray J, Kavanagh C, Graham S, Walsh M. Design and pilot evaluation of an Internet spit tobacco cessation program. J Dent Hyg 2008;82(1):11. [Medline: 18269812]

52. Glasgow RE, Boles SM, McKay HG, Feil EG, Barrera Jr M. The D-Net diabetes self-management program: long-term implementation, outcomes, and generalization results. Prev Med 2003 Apr;36(4):410-419. [Medline: 12649049]

53. Gold BC, Burke S, Pintauro S, Buzzell P, Harvey-Berino J. Weight loss on the web: a pilot study comparing a structured behavioral intervention to a commercial program. Obesity (Silver Spring) 2007 Jan;15(1):155-164 [FREE Full text] [doi: 10.1038/oby.2007.520] [Medline: 17228043]

54. Gotsis M, Wang H, Spruijt-Metz D, Jordan-Marsh M, Valente TW. Wellness partners: design and evaluation of a web-based physical activity diary with social gaming features for adults. JMIR Res Protoc 2013 Feb 01;2(1):e10 [FREE Full text] [doi: 10.2196/resprot.2132] [Medline: 23611986]

55. Graham AL, Cobb NK, Papandonatos GD, Moreno JL, Kang H, Tinkelman DG, et al. A randomized trial of Internet and telephone treatment for smoking cessation. Arch Intern Med 2011 Jan 10;171(1):46-53 [FREE Full text] [doi: 10.1001/archinternmed.2010.451] [Medline: 21220660]

56. Graham ML, Uesugi KH, Niederdeppe J, Gay GK, Olson CM. The theory, development, and implementation of an e-intervention to prevent excessive gestational weight gain: e-Moms Roc. Telemed J E Health 2014 Dec;20(12):1135-1142 [FREE Full text] [doi: 10.1089/tmj.2013.0354] [Medline: 25354350]

57. Greene J, Sacks R, Piniewski B, Kil D, Hahn JS. The impact of an online social network with wireless monitoring devices on physical activity and weight loss. J Prim Care Community Health 2013 Jul 01;4(3):189-194. [doi:

10.1177/2150131912469546] [Medline: 23799706]

58. Haines-Saah RJ, Kelly MT, Oliffe JL, Bottorff JL. Picture Me Smokefree: a qualitative study using social media and digital photography to engage young adults in tobacco reduction and cessation. J Med Internet Res 2015 Jan 26;17(1):e27 [FREE Full text] [doi: 10.2196/jmir.4061] [Medline: 25624064]

59. Haire-Joshu DL, Schwarz CD, Peskoe SB, Budd EL, Brownson RC, Joshu CE. A group randomized controlled trial integrating obesity prevention and control for postpartum adolescents in a home visiting program. Int J Behav Nutr Phys Act 2015 Jun 26;12:88 [FREE Full text] [doi: 10.1186/s12966-015-0247-8] [Medline: 26112041]

60. Hales SB, Davidson C, Turner-McGrievy GM. Varying social media post types differentially impacts engagement in a behavioral weight loss intervention. Transl Behav Med 2014 Dec;4(4):355-362 [FREE Full text] [doi: 10.1007/s13142-014-0274-z] [Medline: 25584084]

61. Hansen AW, Grønbæk M, Helge JW, Severin M, Curtis T, Tolstrup JS. Effect of a Web-based intervention to promote physical activity and improve health among physically inactive adults: a population-based randomized controlled trial. $\mathrm{J}$ Med Internet Res 2012 Oct 30;14(5):e145 [FREE Full text] [doi: 10.2196/jmir.2109] [Medline: 23111127]

62. Harvey-Berino J, Pintauro S, Buzzell P, Gold EC. Effect of internet support on the long-term maintenance of weight loss. Obes Res 2004 Feb;12(2):320-329 [FREE Full text] [doi: 10.1038/oby.2004.40] [Medline: 14981225]

63. Harvey-Berino J, Pintauro SJ, Gold EC. The feasibility of using Internet support for the maintenance of weight loss. Behav Modif 2002 Jan;26(1):103-116. [doi: 10.1177/0145445502026001006] [Medline: 11799651]

64. Harvey-Berino J, Pintauro S, Buzzell P, DiGiulio M, Casey GB, Moldovan C, et al. Does using the Internet facilitate the maintenance of weight loss? Int J Obes Relat Metab Disord 2002 Sep;26(9):1254-1260. [doi: 10.1038/sj.ijo.0802051] [Medline: 12187404$]$

65. Harvey-Berino J, West D, Krukowski R, Prewitt E, VanBiervliet A, Ashikaga T, et al. Internet delivered behavioral obesity treatment. Prev Med 2010 Aug;51(2):123-128 [FREE Full text] [doi: 10.1016/j.ypmed.2010.04.018] [Medline: 20478333]

66. Helander E, Kaipainen K, Korhonen I, Wansink B. Factors related to sustained use of a free mobile app for dietary self-monitoring with photography and peer feedback: retrospective cohort study. J Med Internet Res 2014 Apr 15;16(4):e109 [FREE Full text] [doi: 10.2196/jmir.3084] [Medline: 24735567] 
67. Herring SJ, Cruice JF, Bennett GG, Davey A, Foster GD. Using technology to promote postpartum weight loss in urban, low-income mothers: a pilot randomized controlled trial. J Nutr Educ Behav 2014;46(6):610-615 [FREE Full text] [doi: 10.1016/j.jneb.2014.06.002] [Medline: 25069621]

68. Hester RK, Delaney HD, Campbell W, Handmaker N. A web application for moderation training: initial results of a randomized clinical trial. J Subst Abuse Treat 2009 Oct;37(3):266-276 [FREE Full text] [doi: 10.1016/j.jsat.2009.03.001] [Medline: 19339137]

69. Holtz B, Krein SL, Bentley DR, Hughes ME, Giardino ND, Richardson CR. Comparison of Veteran experiences of low-cost, home-based diet and exercise interventions. J Rehabil Res Dev 2014;51(1):149-160 [FREE Full text] [doi: 10.1682/JRRD.2013.04.0088] [Medline: 24805901]

70. Houston TK, Sadasivam RS, Allison JJ, Ash AS, Ray MN, English TM, et al. Evaluating the QUIT-PRIMO clinical practice ePortal to increase smoker engagement with online cessation interventions: a national hybrid type 2 implementation study. Implement Sci 2015 Nov 02;10:154 [FREE Full text] [doi: 10.1186/s13012-015-0336-8] [Medline: 26525410]

71. Hurling R, Catt M, Boni MD, Fairley BW, Hurst T, Murray P, et al. Using internet and mobile phone technology to deliver an automated physical activity program: randomized controlled trial. J Med Internet Res 2007 Apr 27;9(2):e7 [FREE Full text] [doi: 10.2196/jmir.9.2.e7] [Medline: 17478409 ]

72. Hwang KO, Etchegaray JM, Sciamanna CN, Bernstam EV, Thomas EJ. Structural social support predicts functional social support in an online weight loss programme. Health Expect 2014 Jun;17(3):345-352 [FREE Full text] [doi:

10.1111/j.1369-7625.2011.00759.x] [Medline: 22212418]

73. Irwin BC, Feltz DL, Kerr NL. Silence is golden: effect of encouragement in motivating the weak link in an online exercise video game. J Med Internet Res 2013 Jun 04;15(6):e104 [FREE Full text] [doi: 10.2196/jmir.2551] [Medline: 23732514]

74. Japuntich SJ, Zehner ME, Smith SS, Jorenby DE, Valdez JA, Fiore MC, et al. Smoking cessation via the internet: a randomized clinical trial of an internet intervention as adjuvant treatment in a smoking cessation intervention. Nicotine Tob Res 2006 Dec;8(Suppl 1):S59-S67. [Medline: 17491172]

75. Johnson F, Wardle J. The association between weight loss and engagement with a web-based food and exercise diary in a commercial weight loss programme: a retrospective analysis. Int J Behav Nutr Phys Act 2011 Aug 02;8:83 [FREE Full text] [doi: 10.1186/1479-5868-8-83] [Medline: 21810222]

76. Johnston JD, Massey AP, Devaneaux CA. Innovation in weight loss programs: a 3-dimensional virtual-world approach. J Med Internet Res 2012 Sep 20;14(5):e120 [FREE Full text] [doi: 10.2196/jmir.2254] [Medline: 22995535]

77. Jones M, Luce KH, Osborne MI, Taylor K, Cunning D, Doyle AC, et al. Randomized, controlled trial of an internet-facilitated intervention for reducing binge eating and overweight in adolescents. Pediatrics 2008 Mar;121(3):453-462. [doi: 10.1542/peds.2007-1173] [Medline: 18310192]

78. Jones M, Taylor LK, Kass AE, Burrows A, Williams J, Wilfley DE, et al. Healthy weight regulation and eating disorder prevention in high school students: a universal and targeted Web-based intervention. J Med Internet Res 2014 Feb 27;16(2):e57 [FREE Full text] [doi: 10.2196/jmir.2995] [Medline: 24583683]

79. Kass AE, Trockel M, Safer DL, Sinton MM, Cunning D, Rizk MT, et al. Internet-based preventive intervention for reducing eating disorder risk: a randomized controlled trial comparing guided with unguided self-help. Behav Res Ther 2014 Dec;63:90-98 [FREE Full text] [doi: 10.1016/j.brat.2014.09.010] [Medline: 25461783]

80. Kelty TL, Morgan PJ, Lubans DR. Efficacy and feasibility of the "Girls' Recreational Activity Support Program Using Information Technology": a pilot randomised controlled trial. APE 2012;02(01):10-16. [doi: 10.4236/ape.2012.21002]

81. Khalil A, Abdallah S. Harnessing social dynamics through persuasive technology to promote healthier lifestyle. Comput Human Behav 2013 Nov;29(6):2674-2681. [doi: 10.1016/j.chb.2013.07.008]

82. King AC, Hekler EB, Grieco LA, Winter SJ, Sheats JL, Buman MP, et al. Harnessing different motivational frames via mobile phones to promote daily physical activity and reduce sedentary behavior in aging adults. PLoS One 2013;8(4):e62613 [FREE Full text] [doi: 10.1371/journal.pone.0062613] [Medline: 23638127]

83. Kulik NL, Fisher EB, Ward DS, Ennett ST, Bowling JM, Tate DF. Peer support enhanced social support in adolescent females during weight loss. Am J Health Behav 2014 Sep;38(5):789-800. [doi: 10.5993/AJHB.38.5.16] [Medline: 24933148]

84. Kullgren JT, Harkins KA, Bellamy SL, Gonzales A, Tao Y, Zhu J, et al. A mixed-methods randomized controlled trial of financial incentives and peer networks to promote walking among older adults. Health Educ Behav 2014 Oct;41(1 Suppl):43S-50S [FREE Full text] [doi: 10.1177/1090198114540464] [Medline: 25274710]

85. Kuwata S, Taniguchi S, Kato A, Inoue K, Yamamoto N, Ohkura T, et al. Metaboli-Net: online groupware system providing counseling guidance for patients with metabolic syndrome. Stud Health Technol Inform 2010;156:65-70. [Medline: 20543340]

86. Liebreich T, Plotnikoff RC, Courneya KS, Boulé N. Diabetes NetPLAY: a physical activity website and linked email counselling randomized intervention for individuals with type 2 diabetes. Int J Behav Nutr Phys Act 2009 Mar 27;6:18 [FREE Full text] [doi: 10.1186/1479-5868-6-18] [Medline: 19327141]

87. Lin JJ, Mamykina L, Lindtner S, Delajoux G, Strub HB. Fish'n'Steps encouraging physical activity with an interactive computer game. In: Proceedings of the 8th International Conference on Ubiquitous Computing. Berlin, Heidelberg: Springer-Verlag; 2006:261-278. 
88. Linehan C, Doughty M, Lawson S, Kirman B, Olivier P, Moynihan P. Tagliatelle: social tagging to encourage healthier eating. 2010 Presented at: Proceedings of the 28th of the International Conference on Human factors in Computing Systems; 10-15 April, 2010; Atlanta, GA, USA p. 3331-3336. [doi: 10.1145/1753846.1753980]

89. Lorig KR, Ritter PL, Laurent DD, Plant K. Internet-based chronic disease self-management: a randomized trial. Med Care 2006 Nov;44(11):964-971. [doi: 10.1097/01.mlr.0000233678.80203.c1] [Medline: 17063127]

90. Lorig K, Ritter PL, Laurent DD, Plant K, Green M, Jernigan VB, et al. Online diabetes self-management program: a randomized study. Diabetes Care 2010 Jun;33(6):1275-1281 [FREE Full text] [doi: 10.2337/dc09-2153] [Medline: 20299481]

91. Maher C, Ferguson M, Vandelanotte C, Plotnikoff R, De Bourdeaudhuij BI, Thomas S, et al. A web-based, social networking physical activity intervention for insufficiently active adults delivered via Facebook app: randomized controlled trial. $\mathrm{J}$ Med Internet Res 2015 Jul 13;17(7):e174 [FREE Full text] [doi: 10.2196/jmir.4086] [Medline: 26169067]

92. Bramlett MA, Harrison JA. Safe eats: an evaluation of the use of social media for food safety education. J Food Prot 2012 Aug;75(8):1453-1463. [doi: 10.4315/0362-028X.11-551] [Medline: 22856569]

93. McKay HG, King D, Eakin EG, Seeley JR, Glasgow RE. The diabetes network internet-based physical activity intervention: a randomized pilot study. Diabetes Care 2001 Aug;24(8):1328-1334. [Medline: 11473065]

94. McKay HG, Danaher BG, Seeley JR, Lichtenstein E, Gau JM. Comparing two web-based smoking cessation programs: randomized controlled trial. J Med Internet Res 2008 Nov 18;10(5):e40 [FREE Full text] [doi: 10.2196/jmir.993] [Medline: 19017582]

95. Meeussen L, Put C, Meganck J, De Peuter S. The gap between attitudes and use in prediction of effect of an online smoking cessation program. J Health Commun 2012;17(8):946-959. [doi: 10.1080/10810730.2012.665419] [Medline: 22724549]

96. Mehring M, Haag M, Linde K, Wagenpfeil S, Frensch F, Blome J, et al. Effects of a general practice guided web-based weight reduction program--results of a cluster-randomized controlled trial. BMC Fam Pract 2013 Jun 07;14:76 [FREE Full text] [doi: 10.1186/1471-2296-14-76] [Medline: 23981507]

97. Merchant G, Weibel N, Patrick K, Fowler FH, Norman GJ, Gupta A, et al. Click "like" to change your behavior: a mixed methods study of college students' exposure to and engagement with Facebook content designed for weight loss. J Med Internet Res 2014 Jun 24;16(6):e158 [FREE Full text] [doi: 10.2196/jmir.3267] [Medline: 24964294]

98. Micco N, Gold B, Buzzell P, Leonard H, Pintauro S, Harvey-Berino J. Minimal in-person support as an adjunct to internet obesity treatment. Ann Behav Med 2007 Feb;33(1):49-56. [doi: 10.1207/s15324796abm3301 6] [Medline: 17291170$]$

99. Morgan PJ, Lubans DR, Collins CE, Warren JM, Callister R. The SHED-IT randomized controlled trial: evaluation of an Internet-based weight-loss program for men. Obesity (Silver Spring) 2009 Nov;17(11):2025-2032 [FREE Full text] [doi: 10.1038/oby.2009.85] [Medline: 19343018]

100. Morgan PJ, Lubans DR, Collins CE, Warren JM, Callister R. 12-month outcomes and process evaluation of the SHED-IT RCT: an internet-based weight loss program targeting men. Obesity (Silver Spring) 2011 Jan;19(1):142-151 [FREE Full text] [doi: 10.1038/oby.2010.119] [Medline: 20523304]

101. Mouton A, Cloes M. Efficacy of a web-based, center-based or combined physical activity intervention among older adults. Health Educ Res 2015 Jun;30(3):422-435. [doi: 10.1093/her/cyv012] [Medline: 25772974]

102. Muñoz RF, Barrera AZ, Delucchi K, Penilla C, Torres LD, Pérez-Stable EJ. International Spanish/English Internet smoking cessation trial yields 20\% abstinence rates at 1 year. Nicotine Tob Res 2009 Sep;11(9):1025-1034 [FREE Full text] [doi: 10.1093/ntr/ntp090] [Medline: 19640833]

103. Muñoz RF, Aguilera A, Schueller SM, Leykin Y, Pérez-Stable EJ. From online randomized controlled trials to participant preference studies: morphing the San Francisco Stop Smoking site into a worldwide smoking cessation resource. J Med Internet Res 2012 Jun 27;14(3):e64 [FREE Full text] [doi: 10.2196/jmir.1852] [Medline: 22739225]

104. Munson SA, Consolvo S. Exploring goal-setting, rewards, self-monitoring, and sharing to motivate physical activity. : IEEE; 2012 Presented at: Pervasive Computing Technologies for Healthcare (PervasiveHealth), 6th International Conference on Pervasive Computing Technologies for Healthcare (PervasiveHealth) and Workshops; 21-24 May 2012; San Diego, CA, USA p. 25-32. [doi: 10.4108/icst.pervasivehealth.2012.248691]

105. Napolitano MA, Hayes S, Bennett GG, Ives AK, Foster GD. Using Facebook and text messaging to deliver a weight loss program to college students. Obesity (Silver Spring) 2013 Jan;21(1):25-31 [FREE Full text] [doi: 10.1002/oby.20232] [Medline: 23505165]

106. Obermayer JL, Riley WT, Asif O, Jean-Mary J. College smoking-cessation using cell phone text messaging. J Am Coll Health 2004;53(2):71-78. [doi: 10.3200/JACH.53.2.71-78] [Medline: 15495883]

107. Patten CA, Croghan IT, Meis TM, Decker PA, Pingree S, Colligan RC, et al. Randomized clinical trial of an Internet-based versus brief office intervention for adolescent smoking cessation. Patient Educ Couns 2006 Dec;64(1-3):249-258. [doi: 10.1016/j.pec.2006.03.001] [Medline: 16616449 ]

108. Pullen CH, Hageman PA, Boeckner L, Walker SN, Oberdorfer MK. Feasibility of Internet-delivered weight loss interventions among rural women ages 50-69. J Geriatr Phys Ther 2008;31(3):105-112. [Medline: 19856616]

109. Richardson CR, Buis LR, Janney AW, Goodrich DE, Sen A, Hess ML, et al. An online community improves adherence in an internet-mediated walking program. Part 1: results of a randomized controlled trial. J Med Internet Res 2010 Dec 17;12(4):e71 [FREE Full text] [doi: 10.2196/jmir.1338] [Medline: 21169160] 
110. Riley W, Obermayer J, Jean-Mary J. Internet and mobile phone text messaging intervention for college smokers. J Am Coll Health 2008;57(2):245-248. [doi: 10.3200/JACH.57.2.245-248] [Medline: 18809542]

111. Riper H, Kramer J, Smit F, Conijn B, Schippers G, Cuijpers P. Web-based self-help for problem drinkers: a pragmatic randomized trial. Addiction 2008 Feb;103(2):218-227. [doi: 10.1111/j.1360-0443.2007.02063.x] [Medline: 18199300]

112. Rodgers A, Corbett T, Bramley D, Riddell T, Wills M, Lin RB, et al. Do u smoke after txt? Results of a randomised trial of smoking cessation using mobile phone text messaging. Tob Control 2005 Aug;14(4):255-261 [FREE Full text] [doi: 10.1136/tc.2005.011577] [Medline: 16046689]

113. Rotheram-Borus MJ, Tomlinson M, Gwegwe M, Comulada WS, Kaufman N, Keim M. Diabetes buddies: peer support through a mobile phone buddy system. Diabetes Educ 2012;38(3):357-365 [FREE Full text] [doi: 10.1177/0145721712444617] [Medline: 22546740]

114. Schneider KL, Murphy D, Ferrara C, Oleski J, Panza E, Savage C, et al. An online social network to increase walking in dog owners: a randomized trial. Med Sci Sports Exerc 2015 Mar;47(3):631-639 [FREE Full text] [doi: 10.1249/MSS.0000000000000441] [Medline: 25003777]

115. Schweier R, Romppel M, Richter C, Hoberg E, Hahmann H, Scherwinski I, et al. A web-based peer-modeling intervention aimed at lifestyle changes in patients with coronary heart disease and chronic back pain: sequential controlled trial. J Med Internet Res 2014 Jul 23;16(7):e177 [FREE Full text] [doi: 10.2196/jmir.3434] [Medline: 25057119]

116. Spittaels H, De Bourdeaudhuij I, Vandelanotte C. Evaluation of a website-delivered computer-tailored intervention for increasing physical activity in the general population. Prev Med 2007 Mar;44(3):209-217. [doi: 10.1016/j.ypmed.2006.11.010] [Medline: 17197015]

117. Stoddard JL, Augustson EM, Moser RP. Effect of adding a virtual community (bulletin board) to smokefree.gov: randomized controlled trial. J Med Internet Res 2008 Dec 19;10(5):e53 [FREE Full text] [doi: 10.2196/jmir.1124] [Medline: 19097974]

118. Sugano M, Yamazaki C. Behavioral analysis of SNS users with regard to diet. 2011 Presented at: IADIS International Conference Web Based Communities and Social Media 2011; July 20-26, 2011; Rome p. 167-170.

119. Svetkey LP, Stevens VJ, Brantley PJ, Appel LJ, Hollis JF, Loria CM, Weight Loss Maintenance Collaborative Research Group. Comparison of strategies for sustaining weight loss: the weight loss maintenance randomized controlled trial. J Am Med Assoc 2008 Mar 12;299(10):1139-1148. [doi: 10.1001/jama.299.10.1139] [Medline: 18334689]

120. Stevens VJ, Funk KL, Brantley PJ, Erlinger TP, Myers VH, Champagne CM, et al. Design and implementation of an interactive website to support long-term maintenance of weight loss. J Med Internet Res 2008 Jan 25;10(1):e1 [FREE Full text] [doi: 10.2196/jmir.931] [Medline: 18244892]

121. Swan GE, McClure JB, Jack LM, Zbikowski SM, Javitz HS, Catz SL, et al. Behavioral counseling and varenicline treatment for smoking cessation. Am J Prev Med 2010 May;38(5):482-490 [FREE Full text] [doi: 10.1016/j.amepre.2010.01.024] [Medline: 20409497]

122. Tate DF, Wing RR, Winett RA. Using Internet technology to deliver a behavioral weight loss program. J Am Med Assoc 2001 Mar 07;285(9):1172-1177. [Medline: 11231746]

123. Tate DF, Jackvony EH, Wing RR. Effects of Internet behavioral counseling on weight loss in adults at risk for type 2 diabetes: a randomized trial. J Am Med Assoc 2003 Apr 09;289(14):1833-1836. [doi: 10.1001/jama.289.14.1833] [Medline: 12684363]

124. Tate DF, Jackvony EH, Wing RR. A randomized trial comparing human e-mail counseling, computer-automated tailored counseling, and no counseling in an Internet weight loss program. Arch Intern Med 2006;166(15):1620-1625. [doi: 10.1001/archinte.166.15.1620] [Medline: 16908795]

125. Taylor CB, Bryson S, Luce KH, Cunning D, Doyle AC, Abascal LB, et al. Prevention of eating disorders in at-risk college-age women. Arch Gen Psychiatry 2006 Aug;63(8):881-888 [FREE Full text] [doi: 10.1001/archpsyc.63.8.881] [Medline: 16894064]

126. Thrul J, Klein AB, Ramo DE. Smoking cessation intervention on Facebook: which content generates the best engagement? J Med Internet Res 2015 Nov 11;17(11):e244 [FREE Full text] [doi: 10.2196/jmir.4575] [Medline: 26561529]

127. Toscos T, Faber A, Connelly K, Upoma AM. Encouraging physical activity in teens Can technology help reduce barriers to physical activity in adolescent girls? : IEEE; 2008 Presented at: Second International Conference on Pervasive Computing Technologies for Healthcare; 2008; Tampere p. 218-221 URL: http://ieeexplore.ieee.org/stamp/stamp. jsp?tp=\&arnumber=4571073\&isnumber=4571002 [doi: 10.1109/PCTHEALTH.2008.4571073]

128. Touger-Decker R, Denmark R, Bruno M, O'Sullivan-Maillet J, Lasser N. Workplace weight loss program; comparing live and internet methods. J Occup Environ Med 2010 Nov;52(11):1112-1118. [doi: 10.1097/JOM.0b013e3181f9ee8c] [Medline: 21063189]

129. Turner-McGrievy GM, Davidson CR, Wingard EE, Billings DL. Low glycemic index vegan or low-calorie weight loss diets for women with polycystic ovary syndrome: a randomized controlled feasibility study. Nutr Res 2014 Jun;34(6):552-558. [doi: 10.1016/j.nutres.2014.04.011] [Medline: 25026923]

130. Valle CG, Tate DF, Mayer DK, Allicock M, Cai J. A randomized trial of a Facebook-based physical activity intervention for young adult cancer survivors. J Cancer Surviv 2013 Sep;7(3):355-368 [FREE Full text] [doi: 10.1007/s11764-013-0279-5] [Medline: 23532799] 
131. van Genugten L, van Empelen P, Boon B, Borsboom G, Visscher T, Oenema A. Results from an online computer-tailored weight management intervention for overweight adults: randomized controlled trial. J Med Internet Res 2012 Mar 14;14(2):e44 [FREE Full text] [doi: 10.2196/jmir.1901] [Medline: 22417813]

132. Verheijden M, Bakx JC, Akkermans R, van den Hoogen H, Godwin NM, Rosser W, et al. Web-based targeted nutrition counselling and social support for patients at increased cardiovascular risk in general practice: randomized controlled trial. J Med Internet Res 2004 Dec 16;6(4):e44 [FREE Full text] [doi: 10.2196/jmir.6.4.e44] [Medline: 15631968]

133. Walsh G, Golbeck J. StepCity: a preliminary investigation of a personal informatics-based social game on behavior change. New York, NY, USA: ACM; 2014 Presented at: CHI '14 Extended Abstracts on Human Factors in Computing Systems; 2014; Toronto, Ontario, Canada p. 2371-2376. [doi: 10.1145/2559206.2581326]

134. Wangberg SC, Nilsen O, Antypas K, Gram IT. Effect of tailoring in an internet-based intervention for smoking cessation: randomized controlled trial. J Med Internet Res 2011 Dec 15;13(4):e121 [FREE Full text] [doi: 10.2196/jmir.1605] [Medline: 22169631]

135. Webber KH, Tate DF, Michael BJ. A randomized comparison of two motivationally enhanced Internet behavioral weight loss programs. Behav Res Ther 2008 Sep;46(9):1090-1095. [doi: 10.1016/j.brat.2008.06.008] [Medline: 18675402]

136. Webber KH, Tate DF, Ward DS, Bowling JM. Motivation and its relationship to adherence to self-monitoring and weight loss in a 16-week Internet behavioral weight loss intervention. J Nutr Educ Behav 2010;42(3):161-167. [doi: 10.1016/j.jneb.2009.03.001] [Medline: 20138583]

137. White MA, Martin PD, Newton RL, Walden HM, York-Crowe EE, Gordon ST, et al. Mediators of weight loss in a family-based intervention presented over the internet. Obes Res 2004 Jul;12(7):1050-1059 [FREE Full text] [doi: 10.1038/oby.2004.132] [Medline: 15292468 ]

138. Whittemore R, Jeon S, Grey M. An internet obesity prevention program for adolescents. J Adolesc Health 2013 Apr;52(4):439-447 [FREE Full text] [doi: 10.1016/j.jadohealth.2012.07.014] [Medline: 23299003]

139. Womble LG, Wadden TA, McGuckin BG, Sargent SL, Rothman RA, Krauthamer-Ewing ES. A randomized controlled trial of a commercial internet weight loss program. Obes Res 2004 Jun;12(6):1011-1018 [FREE Full text] [doi: 10.1038/oby.2004.124] [Medline: 15229342]

140. Woodruff SI, Edwards CC, Conway TL, Elliott SP. Pilot test of an Internet virtual world chat room for rural teen smokers. J Adolesc Health 2001 Oct;29(4):239-243. [Medline: 11587907]

141. Woodruff SI, Conway TL, Edwards CC, Elliott SP, Crittenden J. Evaluation of an Internet virtual world chat room for adolescent smoking cessation. Addict Behav 2007 Sep;32(9):1769-1786. [doi: 10.1016/j.addbeh.2006.12.008] [Medline: 17250972]

142. Xu Y, Poole ES, Miller AD, Eiriksdottir E, Catrambone R, Mynatt ED. Designing pervasive health games for sustainability, adaptability and sociability. 2012 May 29 Presented at: Proceedings of the International Conference on the Foundations of Digital Games; 29 May 2012; Raleigh, North Carolina p. 49-56. [doi: 10.1145/2282338.2282352]

143. Turner-McGrievy GM, Tate DF. Tweets, apps, and pods: results of the 6-month Mobile Pounds Off Digitally (Mobile POD) randomized weight-loss intervention among adults. J Med Internet Res 2011 Dec 20;13(4):e120 [FREE Full text] [doi: 10.2196/jmir.1841] [Medline: 22186428]

144. Turner-McGrievy GM, Tate DF. Weight loss social support in 140 characters or less: use of an online social network in a remotely delivered weight loss intervention. Transl Behav Med 2013 Sep;3(3):287-294 [FREE Full text] [doi: 10.1007/s13142-012-0183-y] [Medline: 24073180]

145. Turner-McGrievy GM, Tate DF. Are we sure that Mobile Health is really mobile? An examination of mobile device use during two remotely-delivered weight loss interventions. Int J Med Inform 2014 May;83(5):313-319 [FREE Full text] [doi: 10.1016/j.ijmedinf.2014.01.002] [Medline: 24556530]

146. Anderson I, Maitland J, Sherwood S, Barkhuus L, Chalmers M, Hall M, et al. Shakra: tracking and sharing daily activity levels with unaugmented mobile phones. Mobile Netw Appl 2007 Aug 3;12(2-3):185-199. [doi: 10.1007/s11036-007-0011-7]

147. Massoudi BL, Olmsted MG, Zhang Y, Carpenter RA, Barlow CE, Huber R. A web-based intervention to support increased physical activity among at-risk adults. J Biomed Inform 2010 Oct;43(5 Suppl):S41-S45 [FREE Full text] [doi: 10.1016/j.jbi.2010.07.012] [Medline: 20696275]

148. Chiauzzi E, Green TC, Lord S, Thum C, Goldstein M. My student body: a high-risk drinking prevention web site for college students. J Am Coll Health 2005;53(6):263-274 [FREE Full text] [doi: 10.3200/JACH.53.6.263-274] [Medline: 15900990]

149. Grimes A, Bednar M, Bolter JD, Grinter RE. EatWell: sharing nutrition-related memories in a low-income community. New York, NY, USA: ACM; 2008 Presented at: Proceedings of the 2008 ACM Conference on Computer Supported Cooperative Work; 2008; San Diego, CA, USA p. 87-96. [doi: 10.1145/1460563.1460579]

150. Health Quality Ontario. Social isolation in community-dwelling seniors: an evidence-based analysis. Ont Health Technol Assess Ser 2008;8(5):1-49 [FREE Full text] [Medline: 23074510]

151. Gasser R, Brodbeck D, Degen M, Luthiger J, Wyss R, Reichlin S. Persuasiveness of a mobile lifestyle coaching application using social facilitation. In: Persuasive Technology: First International Conference on Persuasive Technology for Human Well-Being, PERSUASIVE 2006. Berlin, Heidelberg: Springer; 2006:27-38. 
152. Zuckerman O, Gal-Oz A. Deconstructing gamification: evaluating the effectiveness of continuous measurement, virtual rewards, and social comparison for promoting physical activity. Pers Ubiquit Comput 2014 Jul 5;18(7):1705-1719. [doi: 10.1007/s00779-014-0783-2]

153. McCully SN, Don BP, Updegraff JA. Using the Internet to help with diet, weight, and physical activity: results from the Health Information National Trends Survey (HINTS). J Med Internet Res 2013 Aug 01;15(8):e148 [FREE Full text] [doi: 10.2196/jmir.2612] [Medline: 23906945]

154. Dennison L, Morrison L, Conway G, Yardley L. Opportunities and challenges for smartphone applications in supporting health behavior change: qualitative study. J Med Internet Res 2013 Apr 18;15(4):e86 [FREE Full text] [doi: 10.2196/jmir.2583] [Medline: 23598614]

155. Tanis M. Health-related on-line forums: what's the big attraction? J Health Commun 2008;13(7):698-714. [doi: 10.1080/10810730802415316] [Medline: 18958781$]$

156. Wright KB, Bell SB, Wright KB, Bell SB. Health-related support groups on the Internet: linking empirical findings to social support and computer-mediated communication theory. J Health Psychol 2003 Jan;8(1):39-54. [doi: 10.1177/1359105303008001429] [Medline: 22113899]

\author{
Abbreviations \\ BCI: behavior change intervention \\ DBCIs: digital behavior change interventions \\ ICTs: information and communication technologies \\ OSN: online social network \\ PRISMA: Preferred Reporting Items for Systematic Reviews and Meta-Analyses \\ RCTs: randomized controlled trials \\ SMS: short message service \\ WHO: World Health Organization
}

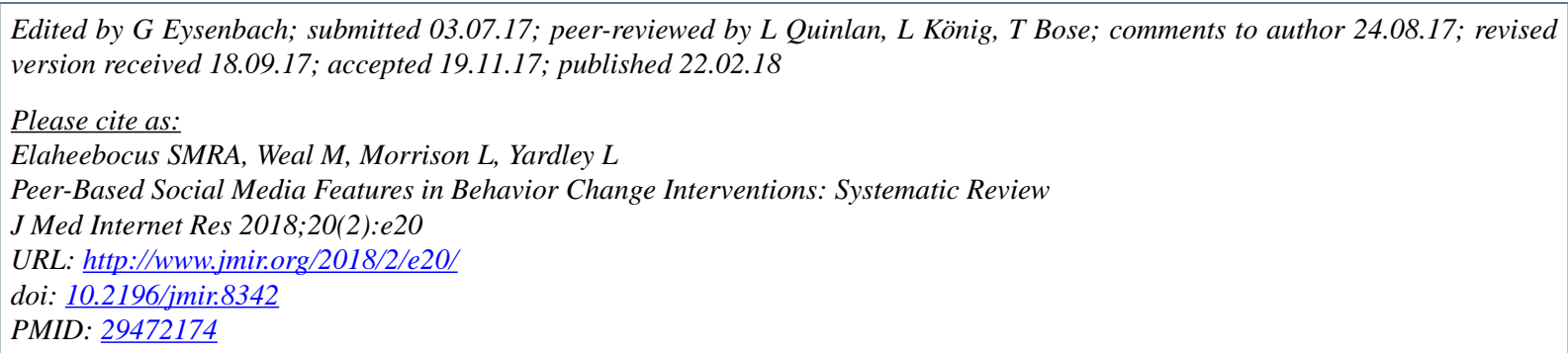

(C) Sheik Mohammad Roushdat Ally Elaheebocus, Mark Weal, Leanne Morrison, Lucy Yardley. Originally published in the Journal of Medical Internet Research (http://www.jmir.org), 22.02.2018. This is an open-access article distributed under the terms of the Creative Commons Attribution License (https://creativecommons.org/licenses/by/4.0/), which permits unrestricted use, distribution, and reproduction in any medium, provided the original work, first published in the Journal of Medical Internet Research, is properly cited. The complete bibliographic information, a link to the original publication on http://www.jmir.org/, as well as this copyright and license information must be included. 